\title{
IT Governance in SMEs: Trust or Control?
}

\author{
Jan Devos ${ }^{1}$, Hendrik Van Landeghem ${ }^{2}$, and Dirk Deschoolmeester ${ }^{2}$ \\ ${ }^{1}$ Ghent University Association \\ ${ }^{2}$ Ghent University
}

\begin{abstract}
It is believed by many scholars that a small and medium-sized enterprise (SME) cannot be seen through the lens of a large firm. Theories which explain IT governance in large organizations and methodologies used by practitioners can therefore not be extrapolated to SMEs, which have a completely different economic, cultural and managerial environment. SMEs suffer from resource poverty, have less IS experience and need more external support. SMEs largely contribute to the failure of many IS projects. We define an outsourced information system failure (OISF) as a failure of IT governance in an SME environment and propose a structure for stating propositions derived from both agency theory and theory of trust. The theoretical question addressed in this paper is: how and why do OISFs occur in SMEs? We have chosen a qualitative and positivistic IS case study research strategy based on multiple cases. Eight cases of IS projects were selected. We found that trust is more important than control issues like output-based contracts and structured controls for eliminating opportunistic behaviour in SMEs. We conclude that the world of SMEs is significantly different from that of large companies. This necessitates extra care to be taken on the part of researchers and practitioners when designing artefacts for SMEs.
\end{abstract}

Keywords: SMEs, Agency Theory, Trust, Case Study.

\section{Introduction}

It is believed by many scholars that a small and medium-sized enterprise (SME) cannot be seen through the lens of a large firm. Therefore theories which explain IT governance in large organisations and methodologies used by practitioners cannot be extrapolated to SMEs, since they have a completely different economical, cultural and managerial environment (Welsh and White 1981). Despite the efforts to develop methods for IT governance in SMEs, like the Cobit QuickStart method, the adoption rate is rather disappointing (IT Governance Institute 2003). IT governance in SMEs is still immature. Both scholars and practitioners, too grounded in their way of thinking, hold simplistic vision of an SME as a small scale model of a large firm (Raymond 1985). We still lack genuine SME-centred theories that can lead to general inferences about how SMEs should conduct IT governance. Riemenschneider et al. stated that: '[...]May be organizational theories and practices, such as bureaucratic structure and organizational behaviour, applicable to large organizations may not be valid in small ones' (Riemenschneider 2003). 
In this work, we focus on the constructs of trust and control in relation to IS projects in SME environments. This paper is based on an ongoing research on IT governance in SMEs and reports on recent research based on a qualitative, positivistic and multiple case study research strategy where we investigate IS failures in an outsourced SME environment. Due to their small scale and hence a lack of in house ITskills, SMEs depend more on IT vendors than large companies (Thong 2001, Thong et al. 1997). However this does not mean that outsourcing is without risks or problems. From a managerial point of view we associate risk in IT outsourcing with negative outcomes. A risk scenario that is of special interest for this research is the occurrence of IS failures. We elaborate on IS failures further in this paper. IS failures can lead to disputes which can be divided into litigation and non-litigation issues since not all IS failures lead to litigation.

Following this introduction, this paper is structured into five parts. The specific relationships between SMEs and IT, with particular focus on the phenomenon of outsourced IS failures, is reviewed in the next part. We elaborate on the theoretical foundations of trust and control in part three. Part four details the research methodology and the research design. Part five presents the results of testing the propositions by the multiple case study method and our empirical observations along with a discussion of our findings and conclusions.

\section{Outsourced IS Failures in SMEs}

Research and literature have highlighted the definitional problems of SMEs. Companies differ in size, location, ownership structure, financial performance, maturity and management style. It is advisable to clearly define an SME before venturing into any research. However this is not obvious. There are many characteristics which identify an SME. The European Commission took an initiative to define a SME in terms of microeconomic characteristics like turnover (not exceeding 50 million euro), annual balance sheet total (not exceeding 43 million euro) and headcount (fewer than 250 persons) (European Commission 2003). This definition is derived from a legal and economic point of view and is not always found accurate when it comes to the study of the relationship between the company and IT. However, this definition is used for our research.

In the years of the dotcom hype, many believed that IT would enable SMEs to compete with large companies. However a lack of readiness towards networking with other enterprises and reluctance to use advanced IT proved otherwise (European Commission 2004). SMEs perceive little incentive to change business models when returns are unclear (OECD 2004). Research also showed that SMEs do not excel in knowledge retention and obtaining a sustainable competitive advantage. There is a slower adoption of IT in SMEs than in large enterprises (Lia et al. 2004, Premkumar 2003). Existing mechanisms of IT governance build on a strong belief that IT creates values for the business; but these do not hold true for SMEs where decision making is mostly centred round one person (Levy et al. 2003, Southern et al. 2000, Lefebvre et al. 1997). SMEs also cannot learn and benefit from past experiences because there are not enough IS projects conducted. 
Existing research on IT and SMEs is fragmented in terms of findings and conceptual approaches (Harrison et al. 1997). In this research, we focus on two major findings: the role of the CEO as the principal decision maker in SMEs (Southern et al. 2000; Lefebvre et al. 1997) and the dependency of SMEs on external IT expertise (Thong 2001, Thong et al. 1997). Thong has shown that both findings are related: "The results show that the most effective IS implementation environment is one in which both top management support and external IS experts work as a team".

Despite the numerous success stories illustrating the advantages of bringing Information Technology into organisations, it is broadly accepted that the processes of designing, developing and implementing are cumbersome and not straightforward. Both recent and older reports show that IS projects frequently fail. A broad and elaborate research on IS failures has been conducted for more than four decennia (Ackoff 1967, Lucas 1975, Lyytinen et al. 1987, Sauer 1993, Keil 1995, Beynon-Davies 1999, Ewushi-Mensah 2003, Iacovou et al. 2005, Avison et al. 2006). Practitioners and expert witnesses report frequent IS failures in SMEs as well as in large companies (Standish Group 2004, Webster 2000).

IS failures can be divided into expectation (Lyytinen et al. 1987) and termination (Sauer 1993) failures. Expectation failures can be categorised into correspondence, process and interaction failures. Correspondence failures occur when IS are oriented towards previous defined design objectives. A lack of correspondence between design objectives and evaluation is seen as a failure. Process failures occur when there is unsatisfactory development performance, i.e., one fails to produce a workable system or to deliver within the budget constraints of time and costs. Process failures are sometimes called 'runaways' or escalating projects (Iacovou 2004, Keil 1995). Interaction failures are situated within the mismatch between requirements and user acceptance. An interaction failure appears when an IS remains unused. In summary, an IS expectation failure is the inability of an IS to meet the expectations of the stakeholders.

Sauer brought up the more pragmatic concept of the termination failure (Sauer 1993). According to Sauer an IS failure can only occur when the development process or operation of an IS causes dissatisfied stakeholders to abandon the project.

We argue that there is an extra dimension to IS failures that is not covered by those descriptive models, which we call the Outsourced IS Failure (OISF). An OISF is a failure that occurs during an IS project in an outsourced environment. We use the taxonomy of Lacity and Hirschheim (Dibbern et al. 2004) of outsourcing options and focus on Project Management. Some academics have already pointed out that outsourcing increases risks leading to IS failures (Natovich 2003, Aubert et al. 2003).

We see an OSIF in a SME as a failure of governing IT in a SME environment and propose a structure for stating propositions derived from both agency theory and the theory of trust in the following section. The theoretical question addressed in this paper is: How and why do OISFs occur in SMEs? An overview of the literature provides strong support for the belief that a lot of OISFs do occur in SMEs and that the construct of trust is of significant importance. Mohtashami et al. stated that: '[...] the absence of a proper level of trust is the primary reason for a larger percentage (40 to $70 \%$ ) of collaboration failure' (Mohtashami et al. 2006). 


\section{Theory: Trust and Control}

The concept of trust is subtle, diffuse and elusive. Although there is agreement on the importance of trust, there also appears disagreement on a suitable definition of the construct (Bigley and Pearce 1998). Trust can be seen as a co-ordinating mechanism based on shared moral values and norms supporting collective co-operation and collaboration within uncertain environments (Reed 2001). Blois gives a number of definitions of trust appearing in frequently quoted papers (Blois 1999). Trust/control relations between organisations can be seen as highly complex structures of social relations and processes which are needed for the generation and maintenance of collective action. The concept of trust is crucial in business interactions that are characterised by mutual dependency combined with a lack of mutual control. Some researchers argue that trust is also reciprocal. According to Reed: ...the essential character of all trust relations is their reciprocal nature. Trust tends to evoke trust, distrust to evoke distrust... . As trust shrinks, distrust takes over... (Reed 2001).

The concept of trust was already used in IS research (Mohtashami et al. 2006, Gefen 2004, Lander et al. 2004, Sahberwal 1999) and in related environments as R\&D (Blomqvist 2005) and business to business relationships (Blois 1999).

A working definition of trust already used in IS research and most suitable for our empirical setting is given by Gefen: 'Trust is the belief that others upon whom one depends, yet has little control over, will not take advantage of the situation by behaving in an opportunistic manner but, rather, will fulfil their expected commitments by behaving ethically, dependably and fairly especially under conditions involving risk and potential loss' (Gefen 2004).

Trust can occur on the personal level or on the organisational level. The latter is also known as institutionalized trust. The concept of personal trust seems to be relevant in family-owned SMEs since in those organizations the central role of the CEO has been identified as a key factor for effective IS implementation (Thong et al. 1997). However, Zaheer et al found interpersonal and organizational trust to be highly correlated (Zaheer et al. 1998).

Sabherwal states that inter-organisational relationships involve a psychological contract and a formal written contract. The written contract is negotiated and well understood, while the psychological contract consists of unwritten and largely unspoken sets of expectations held by the transacting parties about each other's prerogatives and obligations (Sabherwal 1999). Governing IT in an outsourced environment requires dealing with both types of contracts. Trust supports the psychological contract. An outsourced IT project in an SME environment can be seen as an interpersonal cooperation and exchange. Trust limits the need for structured controls by reducing the perceived need to guard against opportunistic behaviour when unexpected changes occur in an IT project. Structural controls are appropriate mechanisms including deliverables, reporting arrangements, meeting schedules, penalty clauses for governing the project and to address compliance with the contract (Sabherwal 1999). Trust can also be seen as a mechanism for reducing complexity. Trust does not go into the complexity itself but tries to avoid or reduce it. Theoretically, the role of trust in an outsourced IS environment, amongst others things, appears to be important.

A predominant theory central to Western management thinking and one of the cornerstones for governance is the Agency Theory (Jensen et al. 1976, Eisenhardt 1986). Agency theory has his roots in the research of decision making and was used as an 
explanation for the theory of firm. Its original setting was the principal as the firm's owner(s) and the agent as the manager(s). Agency theory and derivative theories like formal control theory and IT governance are also very popular theories used in IS research (Aubert et al. 2005, Weil et al. 2004, Choudhury and Sabherwal 2003, Kirsch 2002, Kirsch 1997). Together with transaction cost economy theory, agency theory is seen as a foundation for IS outsourcing (Dibbern et al. 2004). However its contribution is not always very clear since the excessive truth-claims and assumptions of the agency theory are entirely based on analysis in environments other then IT/IS.

Agency theory views problems that occur in outsourced environments as the results of three factors: goal differences, risk behaviour differences and information asymmetry. It is assumed that the agent vendor has private information about the quality of the IS that is not available to the principal (SME). According to agent theory agents can therefore act in their own best interest and exposing opportunistic behaviour which can lead to moral hazard (Tuttle 1997). However when principal and agent are contracting the negotiated transaction can never be described perfectly. Anderlini and Felli state that: '[...]the contracting parties may lack the necessary degree of rationality necessary to describe exactly the various states of nature in the ex-ante contract they draw up.' (Anderline and Felli 2004).

Unlike most theories, agency theory incorporates strongly the concept of the Homo Economicus: a model of people as rational self-interest maximizers. Agency theory inhales a deep mistrust of the principal in the agent and his actions (Ghoshal 2005, Lubatkin 2005). It is precisely in that mistrust where the theory fails to act as a grand IS theory for inducing normative IT governance principles for SMEs.

The complex balancing relationship between trust and control is elaborated by Reed (Reed 2001). Although this relationship can be seen as a nexus there is also rivalry in the theoretical underpinnings. However this rivalry must be seen as commingled rivalry (Yin 2003). The relation of both theories is brought together by Sahberwal (see Figure 1).

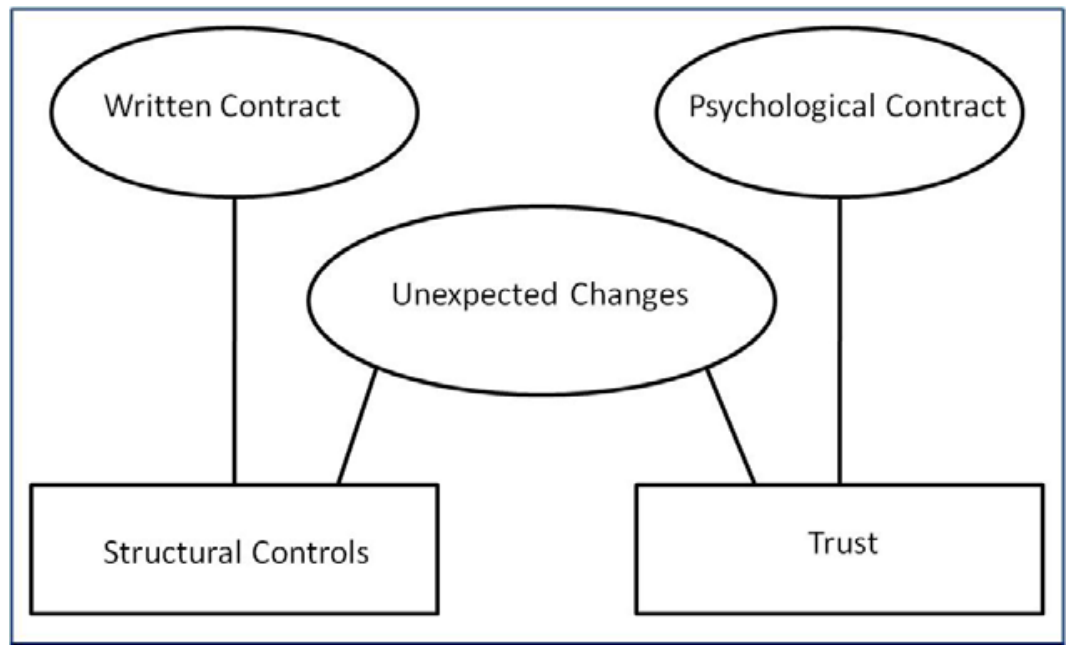

Fig. 1. The complementary nature of structure and trust (R. Sabherwal) 


\section{Research Methodology and Design}

We have chosen a qualitative and positivistic IS case study research strategy based on multiple cases. The choice for qualitative research is based on the accessibility of well documented secondary data in litigation files of failed IS projects in SMEs. Eight cases of IS projects were selected. Most of the projects were subject to litigation. To avoid the difficult problem of defining a failed project, we used the concept of a termination error (Sauer 1993).

OISFs are embedded in an organizational context which is not divisible from the unit of analysis. There are definitely more variables to be studied than there is available data. This is a situation where the case study is an ideal research strategy (Yin 2003, Lee 1989). According to Yin a case study research strategy is useful when a phenomenon cannot be studied outside the context in which it occurs or where the boundaries between phenomenon and context are not clearly evident. Sauer shares the opinion that research in relation to IS failures is best done by case study method (Sauer 1993). The development of the research design and methodology is inspired by the work of researchers experienced in case study research (Eisenhardt 1989, Lee 1989, Dubé et al. 2003).

To explain OISF and the failure of IT governance in SMEs, we draw on agency theory and on the theory of institutional trust to induce test-worthy propositions for our cases. We consider both theories as process theories (Soh et al. 1995, Markus 1988) and as rival or competing theories. Both theories have discrete outcomes that may not occur even when conditions are present and have a logical form in which conditions are expressed in qualifications as necessary or sufficient rather than dependent and independent variables. Time is a crucial factor in both theories since conditions are built up during the course of an IT project. Both theories were studied and can be considered as falsifiable with the potential of deducing logical and consistent propositions (Lee 1989). We also craft rival propositions from the theories. The theories all seem to have explanatory power. We follow the same logic to induce propositions as Sarker et al. (Sarker et al. 1998).

According to agency theory the opportunistic behaviour that eventually can occur is corrected with control. Kirsch views control as encompassing all attempts to ensure that individuals in organisations act in a manner that is consistent with organizational goals and objectives (Kirsch 1997). There are several possibilities to deploy this control. We consider here the creation of an outcome based contract and the implementation of structured controls for obtaining compliance within the contract. It has been shown that an outcome based contract offers the best solution in a setting where there is information asymmetry (Grossman et al. 1983). We come to the following two propositions induced from agency theory:

\section{P1. An OISF must happen if there are no structured controls implemented}

Proposition P1 implies that the absence of implemented structured controls is a sufficient but not necessary condition for an OISF. This also implies that if there are no structured controls implemented and there is no OISF, the proposition is falsified. 


\section{P2. An OISF must happen if the contract is not outcome-based}

Proposition P2 implies that the absence of an outcome-based contract is a sufficient but not necessary condition for an OISF. This also implies that if there is not an outcome-based contract and there is no OISF, the proposition is falsified.

\section{P3. An OISF must happen if (there are no structured controls implemented and the contract is not outcome-based)}

Proposition P3 implies that an outcome-based contract together with (logically "and") the absence of implemented structured controls is a sufficient but not necessary condition for an OISF. This also implies that if the combined condition is true and there is no OISF, the proposition is falsified. Proposition P3 is much stronger than P1 and P1, since both condition (outcome-based contract and structured controls) must appear simultaneously.

We induced also a proposition from institutional trust theory. The operationalisation of the construct trust is based on the work of Lander and Sabherwal who build a classification of trust into three types: calculus-based, knowledge-based and identification-based trust (Sabherwal, 1999, Lander et al. 2004)

Calculus-based or deterrence-based trust is the lowest form of trust and exists when both parties can be trusted to keep their word. The deterrence is rooted in the rewards and punishment of the project and can be found in the project contract. Knowledgebased trust is based on the predictability of the other party developed though knowing the other sufficiently well so that their behaviour is predictable. The highest order of trust is identification-based trust and is developed when one party has "fully internalized the other's wants, and this mutual understanding is developed to the point that each can effectively act for the other" (Lander et al., 2004). The former authors also developed a list with trust-building mechanisms for each level of trust. Based on the characteristic of trust having a reciprocal nature, we looked for distrust evoking events and for trust-building mechanisms in the observations.

We come to the following proposition:

\section{P4. An OISF must happen if there is no trust between the principal (SME CEO) and the agent}

Proposition P4 implies that the absence of trust (or distrust) between both parties in the exchange is a sufficient but not necessary condition for an OISF. This also implies that if there is trust between the principal and the agent and there is an OISF, the proposition is falsified.

The unit of analysis in every case is the IS project in an SME environment that was subject to an OISF. This narrowed down our focus to a bounded system (Paré 2004). Since this is a multiple-case study design we will follow replication logic to offer external validity. Generalisability is of major concern in every research but cannot be of a statistical kind in this work. The kind of generalisation that will be established here is an analytical generalisation (Yin 2003) or generalising from case study findings to theory (Lee and Baskerville 2003). The theoretical generalisation from the empirical description in our case study has no value beyond the given cases. However the generalisation from ideographic details to theory is important for offering clarification of 
theoretical concepts. The cases are therefore carefully chosen to accomplish literal replication logic ( 7 cases) as well as theoretical replication logic (1 case). In each case there is at least some evidence of incomplete and asymmetric information, hidden actions and hidden intentions on behalf of the agent.

We used a longitudinal approach in all cases. Three sources of evidence were used to ensure construct validity: 1) documents, 2) focus and open-ended interviews and 3) direct and participant observations. Project documentation, minutes from steering committee meetings, memorandums and letters were analyzed. Documents were delivered by three sources: plaintiff, defendant and expert witness. The plaintiff and defendant documents were often the same but were brought into litigation for opposed opinions. All expert witness reports were exposed through cross examination of all parties and were corrected if material errors did occur. This resulted in an extra triangulation of the available data. The interviews were recorded on audiotapes and written down in reports and sent to all parties for cross examination. All interviews took place in the present of all parties and the expert witness. The case study sites were visited at least four times for the purpose of doing interviews and direct observations. Additional data was collected during those site visits. In three cases (Rockit, Stones and Boxcars) evidence was obtained as participant observer. The data coming from all sources was coded by means of a coding scheme, which is part of the case study protocol. The coding scheme separates the basic data from the metadata (the documents, reports and sheets). The coding scheme was designed to avoid data contamination. All data is stored in a computerised case study database and links are made between basic data and metadata. The data is retrievable by computer but is also available in original and raw format for reviewers.

Data was analyzed in two steps. First step was a within-case analysis to review the unique patterns of each case. Second a cross-case analysis was conducted in search for common patterns. The cases were selected to allow comparison and to maximise variation while respecting the ceteris paribus criteria so our multiple case study is analogous to multiple experiments as shown in Table 1.

Table 1. The selected cases

\begin{tabular}{|l|l|l|l|l|l|l|l|l|}
\hline $\begin{array}{l}\text { Case } \\
\text { Name }\end{array}$ & Sector & $\begin{array}{l}\text { Ownership } \\
\text { Structure }\end{array}$ & $\begin{array}{l}\text { Turnover } \\
(\text { million })\end{array}$ & Staff & $\begin{array}{l}\text { Type } \\
\text { of Pro- } \\
\text { ject }\end{array}$ & $\begin{array}{l}\text { Cost of } \\
\text { Project }\end{array}$ & Result & $\begin{array}{l}\text { Dispute } \\
\text { Resolution }\end{array}$ \\
\hline Rockit & Textile & Family & $€ 11.64$ & 67 & ERP & $€ 644000$ & No failure & - \\
\hline Woody & Trading & Family & n.a. & $<200$ & SDI & $€ 372000$ & $\begin{array}{l}\text { Process } \\
\text { Failure }\end{array}$ & Litigation \\
\hline Mach & Manufacturing & Family & $€ 12.75$ & 146 & ERP & $€ 90000$ & $\begin{array}{l}\text { Expectation } \\
\text { Failure }\end{array}$ & Litigation \\
\hline Bupo & Software & Family & $€ 0.475$ & 8 & SD & $€ 50000$ & $\begin{array}{l}\text { Process } \\
\text { Failure }\end{array}$ & Litigation \\
\hline Dybo & Trading & Family & $€ 15.65$ & 16 & SDI & $€ 50000$ & $\begin{array}{l}\text { Process } \\
\text { Failure }\end{array}$ & Litigation \\
\hline Stones & Manufacturing & Family & $€ 31.25$ & 200 & ERP & $€ 750000$ & $\begin{array}{l}\text { Expectation } \\
\text { Failure }\end{array}$ & ADR \\
\hline Boxcars & Service & Family & $\begin{array}{l}€ 5.00- \\
€ 20.00\end{array}$ & $10-30$ & DIS & $\begin{array}{l}60 \mathrm{x} \\
€ 75000\end{array}$ & $\begin{array}{l}\text { Expectation } \\
\text { Failure }\end{array}$ & ADR \\
\hline Hero & Service & Family & $€ 4.00$ & 5 & SDI & $€ 75000$ & $\begin{array}{l}\text { Escalation } \\
\text { Failure }\end{array}$ & Litigation \\
\hline
\end{tabular}


Table 2. Overview and summary of case observations

\begin{tabular}{|c|c|c|c|c|}
\hline Observation & Case Rockit & Case Woody & Case Mach & Case Bupo \\
\hline IT Maturity & CMM level 1 & CMM level 1 & CMM level 1 & CMM level 1 \\
\hline Type of contract & Behaviour-based & Outcome-based & Mixed & Outcome-based \\
\hline $\begin{array}{l}\text { Structural controls in con- } \\
\text { tract / in project }\end{array}$ & Yes/No & Yes/Yes & Yes/No & Yes/No \\
\hline Private information (agent) & Yes & Yes & Yes & Yes \\
\hline $\begin{array}{l}\text { Private information (princi- } \\
\text { pal) }\end{array}$ & Yes & No & Yes & No \\
\hline Hidden actions agent & No & Yes & Yes & Yes \\
\hline Hidden actions principal & No & No & Yes & No \\
\hline Lack of commitment (agent) & No & Yes & Yes & Yes \\
\hline $\begin{array}{l}\text { Lack of commitment (prin- } \\
\text { cipal) }\end{array}$ & No & No & No & No \\
\hline Level of trust & Identification & Deterrence & Deterrence & Deterrence \\
\hline Distrust evocation & No & Yes & Yes & Yes \\
\hline Trust deterioration & No & Yes & Yes & Yes \\
\hline Trust-building mechanisms & Yes & No & No & No \\
\hline Observation & Case Dybo & Case Stones & Case Boxcars & Case Hero \\
\hline IT Maturity & CMM level 0 & CMM Level 2 & CMM level 1 & CMM level 0 \\
\hline Type of contract & Mixed & Behaviour-based & Mixed & Outcome-based \\
\hline $\begin{array}{l}\text { Structural controls in con- } \\
\text { tract / in project }\end{array}$ & $\mathrm{No} / \mathrm{No}$ & Yes/Yes & Yes/Yes & Yes/No \\
\hline Private information (agent) & Yes & Yes & Yes & Yes \\
\hline $\begin{array}{l}\text { Private information (princi- } \\
\text { pal) }\end{array}$ & No & No & No & Yes \\
\hline Hidden actions agent & No & Yes & Yes & No \\
\hline Hidden actions principal & No & No & No & No \\
\hline Lack of commitment (agent) & No & No & No & No \\
\hline $\begin{array}{l}\text { Lack of commitment (prin- } \\
\text { cipal) }\end{array}$ & Yes & No & Yes & Yes \\
\hline Level of trust & Deterrence & Knowledge & Deterrence & Deterrence \\
\hline Distrust evocation & Yes & Yes & Yes & Yes \\
\hline Trust deterioration & Yes & No & No & Yes \\
\hline Trust-building mechanisms & No & No & No & No \\
\hline
\end{tabular}

Similarities pertain to the size of the enterprises: all principal sites are family owned SMEs, and there is a strategic importance of the IS project. In terms of variation three projects are ERP implementations, three projects are software development and implementation projects (SDI) and one project is a software development project without implementation (SD). Case Boxcars is a consortium of 60 car dealers who contracted together for a Dealer Information System (DIS). Customizing took place for all ERP projects and the DIS project in the observed cases. The turnover of those firm lays between $€ 5$ million and $€ 20$ million and the headcount between 10 and 30 people. Two cases (Stones and Boxcars) were subject to alternative dispute resolution (ADR).

Table 2 gives an overview of the observations in our research. For each case we looked at:

- Type of contract: two types of contracts are possible: outcome-based and behaviour-based. In some cases a mixed type was discovered in which some parts of the contact were outcome-based (in particular software licences) and others (in particular consultancy fees) were behaviour-based. 
- Structural controls: structural controls appropriate mechanisms including deliverables, reporting arrangements, meeting schedules, penalty clauses for governing the project. We searched for two aspects of structural controls: those stipulated in the contract and those applied during the course of the project.

- Information asymmetry (private information of agent and of principal): traces of private information at both parties.

- Hidden actions (of principal and of agent): traces of hidden actions.

- Lack of commitment: includes the lack of oversight and engagement by executives

- Level of trust: three levels of trust are considered: deterrence-based or calculus-based, knowledge-based and identification-based trust.

- Distrust evocation: f.e. broken promises, lies and personnel changes in the project team.

- Trust deterioration or decline of trust: f.e. parties reacting with formal writings.

- Trust building mechanisms: integrity (fulfilling promises, telling the truth), predictability (consistency, clear roles with responsibilities and accountabilities), communications (openness, receptivity, creating common language), commitment and sharing control.

We summarized the major observations of structural controls (applied during the course of the project), trust and type of contract in table 3 .

Table 3. Summary of the findings

\begin{tabular}{|c|c|c|c|c|}
\hline Trust & $\begin{array}{c}\text { Outcome based } \\
\text { contract }\end{array}$ & $\begin{array}{c}\text { Structural } \\
\text { controls }\end{array}$ & OISF & Case \\
\hline Yes & Yes & Yes & No & - \\
\hline Yes & Yes & No & No & - \\
\hline Yes & No & Yes & No & Stones, Boxcars \\
\hline Yes & No & No & No & Rockit \\
\hline No & Yes & Yes & Yes & Foam, Woody \\
\hline No & Yes & No & Yes & Bupo, Hero \\
\hline No & No & Yes & Yes & - \\
\hline No & No & No & Yes & Dybo \\
\hline
\end{tabular}

\section{Discussion and Conclusions}

Observations indicate that agency theory has certainly predicting power in showing opportunistic behaviour in situations where there is information asymmetry. In all cases we could observe information asymmetry and in five cases this was followed by hidden actions by the agent or the principal. However in one case (Mach) we could also observe hidden actions on behalf of the principal. This is a finding which was already suggested by Moynihan and Aubert: 
'Agency theory views the exchange primarily from the perspective of the principal. But what of the agent's perspective? What strategies can agents use to protect themselves from potentially opportunistic or other unfavourable forms of behaviour on the part of the principal?' (Moynihan 2002)

'Both clients and vendors tend to behave opportunistically when entering into a contract and this can lead to mutual disadvantage.' (Aubert 2003)

Hidden actions on behalf of the agent, once revealed were always leading to an evocation of distrust with the principal.

A match of the findings with proposition P1 are cases Bupo, Hero and Dybo. However in case Rockit we could observe absence of structural controls and no OISF occurred. This leads to the conclusion that proposition P1 is falsified. OISFs do not always happen if there are no structured controls.

Only case Dybo follows a pattern that matches with proposition P2. The cases Stones and Boxcars had no outcome based contracts but an OISF did not occur. Both parties went to alternative dispute resolution. In both cases the CEOs went sitting around the table to work on a solution to save the project and save their future collaboration. An initially OISF which was already ripe to bring into litigation was removed. This leads to the conclusion that proposition P2 is falsified.

The most compelling proposition was P3 in which only case Dybo and Rockit shows a match which the conditions. However in case Rockit there was no OISF, leading to the conclusion that also proposition P3 is falsified.

Finally, all empirical patterns in the cases matches with proposition P4. An OSIF must happen if there is no trust between the principal and the agent.

We can conclude that trust is more important than output-based contracts for eliminating opportunistic behaviour in family-owned SMEs. Even with structural controls in place, trust is necessary to prevent from IS failure. Trust is also more important than structural controls for eliminating opportunistic behaviour in SMEs. The propositions deduced from agency theory are theoretical but not empirical logical. The world of family-owned SMEs is significant different than this of large companies. Although we did not show any evidence that the same findings perhaps also hold for non-SMEs. However we believe that the specific management structure in familyowned SMEs, centred round the CEO as the main decision maker is a discriminating factor.

There is another intriguing finding. In all cases, except case Rockit, we could observe evocation of distrust on behalf of the agent. In those cases we could observe that representatives of the agent made promises in the tender of the outsourced project that could not stand once the project was started. This is due to the lack of observation power of the principal ex ante. These promises often touched the essentials of the projects like commitments on price, budget and quality (functionality). Ex post, when the contract is signed and the endeavour with the agent takes a real start, the agent denies his promises which evokes very early in the project trajectory a mistrust with the principal that could not always be mended during the course of the project since there were no trust-building mechanisms. Those observations are predicted by agency theory and lead to the adverse selection by the principal. This is a most interesting topic which need further investigation.

Our findings are rather surprising for structural controls seeming less important than trust. However we do not conclude that structural controls are pointless in SME 
environments. This could also mean that trust and control are not necessarily full rivalry theories. As Reed stated: ...In short, the conventional dichotomy between normatively-based trust and politically-based control has become unsustainable, as the theoretical and empirical work in organizational analysis has consistently blurred the putative analytical and substantive boundaries between them (Reed, 2001).

We cannot neglect the descriptive power of agency theory in an SME - OISF setting, but the theory evade the issue of trust. Nooteboom comes to similar results in his work on trust, opportunism and governance with the transaction cost economy as underlying theory (Nooteboom 1996). Since transaction cost economy theory is also seen as a founding theory for IS outsourcing this may lead to suggestions for further research on TCE and trust in the same SME-OISF settings.

We argue that in an SME environment social-psychological processes with constructs like trust (and probably also fairness, intuition and empathy) are of more importance to explain the complex IT governance phenomena and therefore are more appropriate for deriving guidelines for practitioners than agency theory and (formal) control theory. Rather the ramifications of our findings is that managerial focus in SMEs is completely different compared to large companies. Since the SME-CEO is the crucial stakeholder of an IS project and taking into account that CEO often lacks commitment, time and knowledge this needs further empirical research. For researchers and practitioners this could means that it would be meaningful to start from the beginning with an focussed orientation to SMEs in their work instead of a derived vision on how things are going in large companies.

We conclude with Claudio Ciborra (2002) who stated that: "We can envisage an alternative approach to overcome the crisis generated by an overdose of methodologies. Let us go back to the basics and encounter the world as it presents itself in our everyday experience. We rely on evidence, intuition, and empathy".

\section{References}

Ackoff, R.L.: Management misinformation systems. Management Science 14(4), 147-156 (1967)

Anderlini, L., Felli, L.: Bounded rationality and incomplete contracts. Research in Economics 58(2004), 3-30 (2004)

Aubert, B.A., Patry, M., Rivard, S.: A tale of two outsourcing contracts - An agency-theoretical perpective. Wirtschaftsinformatik 45(2), 181-190 (2003)

Aubert, B.A., Patry, M., Rivard, S.: A Framework for Information Technology Outsourcing Risk Management. Database for Advances In Information Systems 36(4), 9-28 (2005)

Avison, D., Gregor, S., Wilson, M.: Managerial IT Unconsciousness. Communications of the ACM 49(7), 89-93 (2006)

Bahli, B., Rivard, S.: The information technology outsourcing risk: a transaction cost and agency theory-based perspective. Journal of Information Technology 18(9), 211-221 (2003)

Beynon-Davies, P.: Information systems 'failure': The case of the London ambulance service's computer aided despatch project. European Journal of Information Systems 4(3), 171-184 (1995)

Bigley, G.A., Pearce, J.L.: Straining for Shared Meaning in Organization Science: Problems of Trust and Distrust. Academy of Management Review 23(3), 405-421 (1998) 
Blois, K.J.: Trust in Business to Business Relationships: An Evaluation of Its Status. Journal of Management Studies 36(2), 197-215 (1999)

Blomqvist, K., Hurmelinna, P., Seppänen, R.: Playing the collaboration game right - balancing trust and contracting. Technovation 25(2005), 497-504 (2005)

Choudhury, V., Sabherwal, R.: Portfolios of Control in Outsourced Software development Projects. Information Systems Research 14(3), 291-314 (2003)

Ciborra, C.: The Labyrinths of Information - Challenging the Wisdom of Systems. Oxford University Press, Oxford (2002)

Dibbern, J., Goles, T., Hirschheim, R.: Information Systems Outsourcing: A Survey and Analysis of the Literature. Database for Advances In Information Systems 35(4), 6-102 (2004)

Dubé, L., Paré, G.: Rigor in Information Systems Positivist Case Research: Current Practices, Trends and Recommendations. MIS Quarterly 27(4), 597-635 (2003)

Eisenhardt, K.M.: Agency theory: an assessment and review. Academy of Management Review 14(1), 57-74 (1989)

Eisenhardt, K.M.: Control: Organizational and Economic Approaches. Management Science 31(2), 134-149 (1985)

European Commission, The new SME definition: User guide and model declaration (2003)

European Commission, The Go Digital Awareness Campaign 2001-2003: The main lessons to be learnt (2004)

Ewusi-Mensah, K.: Software Development Failures. MIT Press, Cambridge (2003)

Fink, D.: Guidelines for the successful adoption of information technology in small and medium enterprises. International Journal of Information Management 18(4), 243-253 (1999)

Gefen, D.: What makes an ERP implementation relationship worthwhile: Linking trust mechanisms and ERP usefulness. Journal of Management Information Systems 21(1), 263-288 (2004)

Ghoshal, S.: Bad Management Theories Are Destroying Good Management Practices. Academy of Management Learning \& Education 4(1), 75-91 (2005)

Grossman, S.J., Hart, O.D.: An Analysis of the Principal-Agent Problem. Econometrica 51(1), 7-45 (1983)

Harrison, D.A., Mykytyn Jr., P.P., Riemenschneider, C.K.: Executive Decisions About Adoption of Information Technology in Small Business: Theory and Empirical Tests. Information Systems Research 8(2), 171-195 (1997)

Iacovou, C.L.: Managing MIS Project Failures: A Crisis Management Perspective. PhD dissertation (1999)

IT Governance Institute, Cobit Quickstart, IT Governance Institute (2003)

Jensen, M.C., Meckling, W.H.: Theory of the Firm: Managerial Behavior, Agency Costs and Ownership Structure. Journal of Financial Economics 3(4), 305-360 (1976)

Keil, M.: Pulling the Plug: Software Project Management and the Problem of Project Escalation. MIS Quarterly 19(4), 421-431 (1995)

Kirsch, L.J., Sambamurthy, V., Ko, D.G.: Controlling Information Systems Development Projects: The View from the Client. Management Science 48(4), 484-498 (2002)

Kirsch, L.J.: Portfolios of Control Modes and IS Project Management. Information Systems Research 8(3), 215-239 (1997)

Lander, M.C., Purvis, R.L., McCray, G.E., Leigh, W.: Trust-building mechanisms uitlized in outsourced IS development projects: a case study. Information \& Management 41(2004), 509-528 (2004)

Lee, G., Xia, W.: Organizational size and IT innovation adoption: A meta-analysis. Information \& Management 43(2006), 975-985 (2006) 
Lee, A.S., Baskerville, R.L.: Generalizing generalizability in information system research. Information Systems Research 14(3), 221-243 (2003)

Lee, A.S.: A Scientific Methodology for MIS Case Studies. MIS Quarterly 13(1), 33-50 (1989)

Lefebvre, L.A., Mason, R., Lefebvre, E.: The influence prism in SMEs: The power of CEO's perceptions on technology policy and its organizational impacts. Management Science 43(6), 856-878 (1997)

Levy, M., Loebbecke, C., Powell, P.: SMEs, Co-opetition and Knowledge sharing: The IS role. European Journal of information Systems 12(1), 3-17 (2003)

Lubatkin, M.H.: A Theory of the Firm Only a Microeconomist Could Love. Journal of Management Inquiry 14(2005), 213-216 (2005)

Lucas, H.C.: Why Information Systems Fail. Columbia University Press (1975)

Lyytinen, K., Hirschheim, R.: Information systems failures - a survey and classification of the empirical literature. In: Zorkoczy, P.I. (ed.) Oxford Surveys in Information Technology, vol. 4(1987), pp. 257-309. Oxford University Press, Oxford (1987)

Markus, M.L., Robey, D.: Information Technology and Organizational Change: Causal Structure in Theory and Research. Management Science 34(5), 583-598 (1988)

Mohtashami, M., Marlowe, T., Kirova, V.: Risk Management For Collaborative Software Development. Information Systems Management, 20-30 (2006)

Montazemi, A.R.: How They Manage IT: SMEs in Canada and the US. Communications of the ACM 49(12), 109-112 (2006)

Moynihan, T.: Coping with client-based 'people-problems': the theories-of-action of experienced IS/software project managers. Information \& Management 39, 377-390 (2001)

Natovich, J.: Vendor Related Risks in IT Development: A Chronology of an Outsourced Project Failure. Technology Analysis \& Strategic Management 15(4), 409-419 (2003)

Nooteboom, B.: Trust, Opportunism and Governance: A Process and Control Model. Organization Studies 17(6), 985-1010 (1996)

OECD, ICT, E-Business and SMEs, Paris (2004)

Paré, G.: Investigating Information Systems with Positivist Case Study Research. Communications of the AIS 13(2004), 233-264 (2004)

Raymond, L.: Organizational characteristics and MIS success in the context of small business. MIS Quarterly 9(1), 37-52 (1985)

Reed, I.M.: Organization, Trust and Control: A Realist Analist. Organization Studies 22(2), 201-228 (2001)

Riemenschneider, C.K., Mykytyn Jr., P.P.: What small business executives have learned about managing information technology. Information \& Management 37(2000), 257-269 (2000)

Riemenschneider, C.K., Harrison, P., Mykytyn Jr., P.P.: Understanding IT adoption decisions in small business: integrating current theories. Information \& Management 40(2003), 269 285 (2003)

Ring, P.S., Van De Ven, A.H.: Developmental Processes of Cooperative Interorganizational Relationships. Academy of Management Review 19(1), 90-118 (1994)

Sabherwal, R.: The Role of Trust in Outsourced IS Development Projects. Communications of the ACM 42(2), 80-86 (1999)

Sarker, S., Lee, A.S.: Using A Positivistic Case Research Methodology to Test a Theory about IT-Enabled BPR. In: Proceedings of the 19th ICIS 1998, Helsinki, vol. (7), pp. 237-252 (2002)

Sauer, C.: Why Information Systems Fail: A Case Study Approach, Alfred Wailer, Henley-onThames (1993)

Soh, C., Markus, M.L.: How IT creates business value: a proces theory synthesis. In: Proceedings of the 16th ICIS 1995, Amsterdam, pp. 29-42 (1995) 
Standish Group International, Inc., 2004 Third Quarter Research Report, The Standish Group International, Inc. (2004)

Thong, J., Yap, C.S., Raman, K.S.: Environments for Information Systems Implementation in Small Businesses. Journal of Organizational Computing and Electronic Commerce 7(4), 253-278 (1997)

Thong, J.: Resource constraints and information systems implementation in Singaporean small business. Omega - The International Journal of Management Science 29(2001), 143-156 (2001)

Tuttle, B., Harrell, A., Harrison, P.: Moral Hazard, Ethical Considerations, and the Decision to Implement an Information System. Journal of Management Information Systems 13(4), 777 (1997)

Webster, B.F.: Patterns in IT Litigation: Systems Failure (1976-2000), A Study By PricewaterhousCoopers LLP (2000)

Weill, P., Ross, J.W.: IT Governance - How top Performers Manage IT Decisions Rights for Superior Results. Harvard Business School Press (2004)

Welsh, J.A., White, J.F.: A Small Business Is Not a Little Big Business. Harvard Business Review 59(4), 18-32 (1981)

Yin, R.K.: Case Study Research: Design and Methods. Sage Publications, Thousand Oaks (2003)

Zaheer, A., McEvily, B., Perrone, V.: Does trust matter? Exploring the effects of interorganizational and interpersonal trust on performance. Organization Science 9(2), 141-159 (1998) 